\title{
The mycoflora of wheat field debris, Part III
}

\author{
W. J. JOOSTE*
}

\section{ABSTRACT}

Descriptions are given of four fungus species isolated from stubble of a wheat field in the Heilbron district: Ulocladium botrytis Preuss, Drechslera australiensis (Bugnicourt) Subram. \& Jain ex M. B. Ellis, Cladosporium macrocarpum Preuss, Verticillium fusisporium W. Gams.

\section{RÉSUMÉ}

\section{LA MYCOFLORE DES DÉBRIS DE CHAMPS DE BLÉ. III PARTIE}

On décrit quatre espèces fongiques isolées de chaumes de blé dans un champ du district d' Heilbron: Ulocladium botrytis Preuss, Drechslera australiensis (Bugnicourt) Subram. \& Jain ex M. B. Ellis, Cladosporium macrocarpum Preuss, Verticillium fusisporium $W$. Gams.

This a further report on the fungi isolated from wheat stubble. The object of this study was given in the first paper in this series (Papendorf \& Jooste, 1974). Living cultures of the fungi described here have been deposited in the Potchefstroom University Culture collection and dried cultures in the Mycological Herbarium (PREM) of the Plant Protection Research Institute at 590 Vermeulen Street, Pretoria.
The methods used are those described in previous papers (Papendorf \& Jooste l.c., Jooste, 1976). In addition, the potato-carrot agar used was prepared by making an extract of $30 \mathrm{~g}$ of potatoes and $30 \mathrm{~g}$ of carrots boiled in 1 litre of water for one hour. The extract was filtered and $15 \mathrm{~g}$ of agar added before autoclaving. For scanning electron microscopy the fungi were dried by means of the critical point
Figs 1-4.-Camera lucida drawings of 1 , conidia and conidiophores of Ulocladium botrytis: 2, conidia and conidiophores of Drechslera australiensis; 3 , conidia and conidiophores of Cladosporium macrocarpum; 4, phialides, conidia and chlamydospores of Verticillium fusisporium.
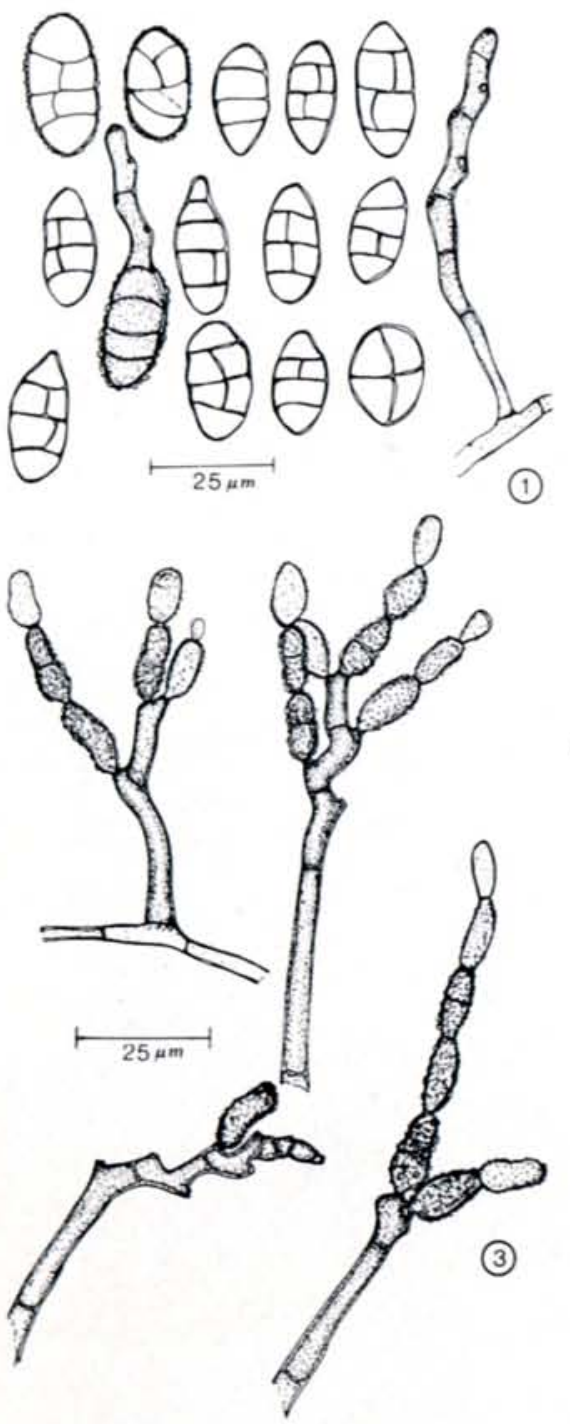

(2)
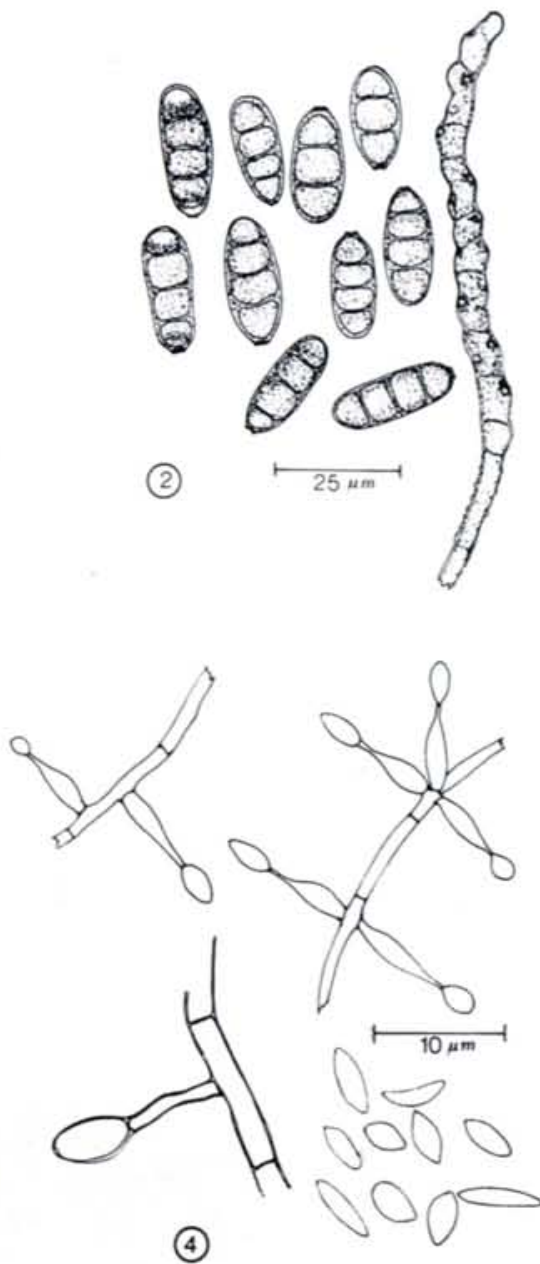

* Institute for Botanical Research, Potchefstroom University for C.H.E., Potchefstroom. 
procedure after dehydration in ethanol and amyl acetate (Cohen, 1970). The dried specimens were coated with silver before scanning with a Cambridge Stereoscan electron microscope.

Ulocladium botrytis Preuss in Simmons, Mycologia 59, 67-91 (1967); Ellis in Dematiaceous Hyphomycetes, Kew: Commonwealth Mycological Institute (1971).

Stemphyllium botryosum Wallr. var. ulocladium Preuss in Sacc. IV, 522 (1886).

Stemphyllium botryosum Wallr. var. botrytis, Lindau in Rabenhorst, Kriptogamen Flora von Deutschland und der Schweiz I. Pilze Abt. IX, 216 (1910).

Figures 1, 10, 11, 12 and 13.

Colonies on potato-carrot agar grow moderately fast, reaching a diameter of $40 \mathrm{~mm}$ in 7 days at $25{ }^{\circ} \mathrm{C}$. Mycelium appressed, smooth, velvety, dark olivaceous-grey to black, buff around the more or less crispate edge of the colony, reverse olivaceousgrey, no pigment diffusing into the agar. Hyphae hyaline to light-honey, branched, septate, smooth to verruculose, fertile hyphae mostly verruculose, 2,05,0 $\mu \mathrm{m}$ diam. Conidiophores mononematous, macronematous, occasionally branched, honey to isabelline, geniculate with up to 8 geniculations, pores conspicuous and one per cell, 35,0-120,0 × 3,0-4,0 $\mu \mathrm{m}$. Conidia solitary, dry verruculose to verrucose or tuberculate, light umber becoming olivaceous black with ageing, mostly with 3 transverse and 2-4 longitudinal septa, slightly constricted at the septa, subglobose, obovoid or ellipsoidal, the latter often conspicuously symmetrical and tapering towards both ends, basal apiculus only conspicuous on obovoid conidia, geniculate false beaks bearing up to eight subglobose or obovoid conidia occur occasionally, conidial dimensions variable, 21,0 $34,0 \times 10,0-14,0 \mu \mathrm{m}$, ave $25,0 \times 12,0 \mu \mathrm{m}$, length: width ratio $2,15: 1$, conidia with false beaks 33,0 $62,5 \times 10,0-12,5 \mu \mathrm{m}$ ave. $47,0 \times 11,8 \mu \mathrm{m}$, beak length $9,0-37,5 \times 3,0-4,0 \mu \mathrm{m}$, ave. $21,0 \times 3,5 \mu \mathrm{m}$.

Specimen examined: P.U. Culture Collection no. 1295, PREM 45012 dried culture on potato-carrot agar.

The characteristic features of this isolate differ in some respects from those noted by Simmons (l.c.) for $U$. botrytis. The conidia are slightly larger and not obovoid as often as indicated by Simmons. A comparison of this isolate with Simmons's cultures of U. botrytis deposited at the CBS revealed that its conidia are regularly more ellipsoidal and not as conspicuously obovoid as those described by Simmons (l.c.). The basal apiculus is not always as prominent as in the case of Simmons's isolates. However, the predominantly three-septate nature of the conidia is a common feature of all the isolates studied. The morphology of the conidia can most satisfactorily be determined in 7-day old cultures. In older cultures the variation in conidial morphology tends to obscure the distinctive characteristics of the species.

Owing to the extreme variability exhibited by species of this genus, it is not justified to describe this isolate as a new species and it is most appropriately named $U$. botrytis.

This is the first record of this species in South Africa.

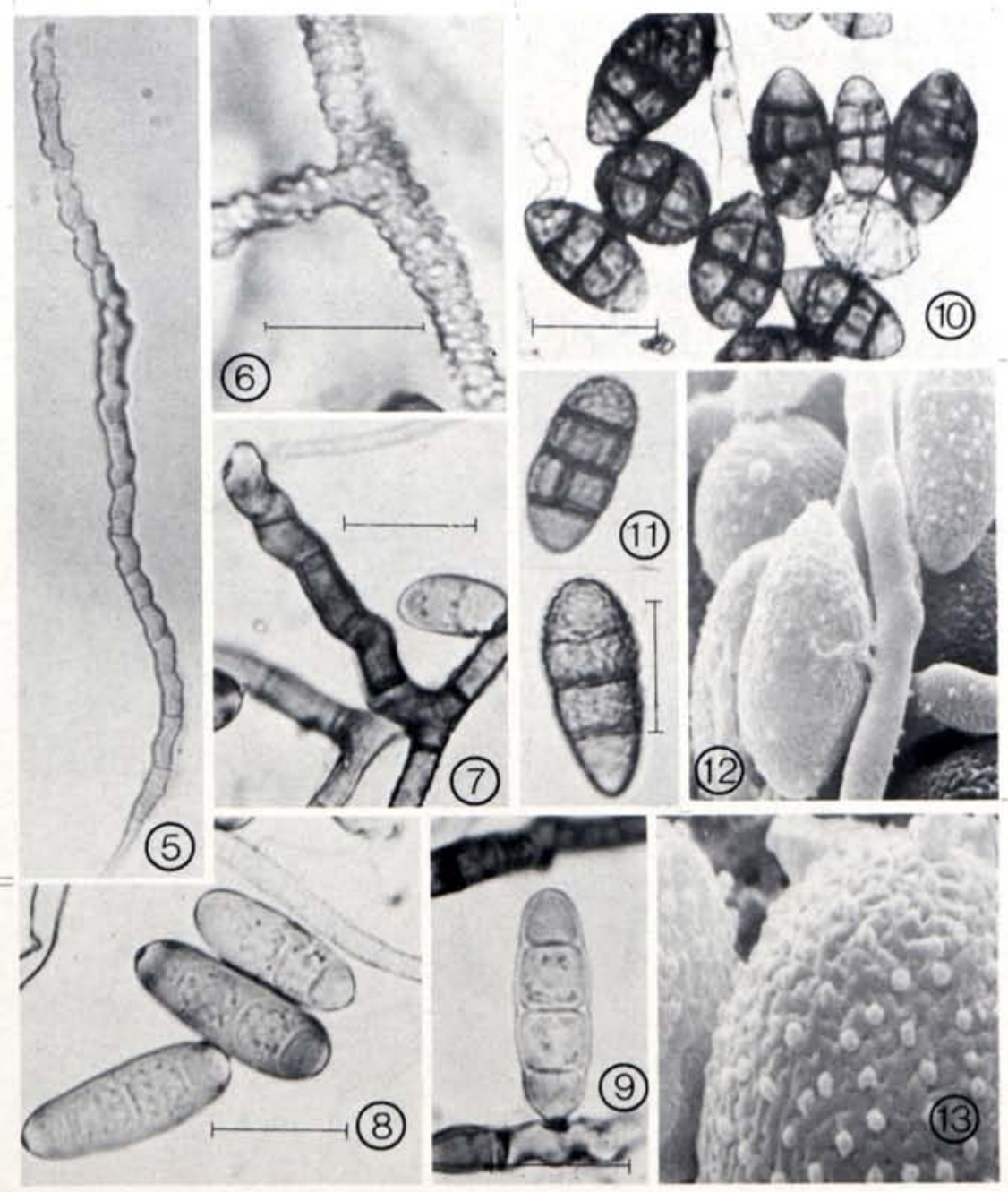

Figs 5-13.-Drechslera australiensis 5. conidiophore; 6 , verrucose hypha; 7 , conidiophore; 8 , conidia showing lighter pigmentation of ends; 9, conidium showing constrictions at septa. Ulocladium botrytis. 10,11 , conidia representing the most characteristic types; scanning electron micrographs showing: 12, characteristic conidium morphology $(\times 1370) ; 13$, surface ornamentation of conidia $(\times 3460)$. Bar in figures represents $10 \mu \mathrm{m}$. 
Drechslera australiensis (Bugnicourt) Subram. \& Jain ex M. B. Ellis in Ellis, Dematiaceous Hyphomycetes, Kew: Commonwealth Mycological Institute (1971).

Helminthosporium australiense Bugnicourt in Revue gen. Bot. 62,242 (1955), (name published invalidly without Latin diagnosis).

Figures 2, 5, 6, 7, 8 and 9 .

Colonies on oatmeal agar grow rapidly, reaching a diameter of $90 \mathrm{~mm}$ in 10 days at $25^{\circ} \mathrm{C}$. Mycelium raised, cottony, varying in colour from very pale olivaceous-grey to olivaceous-grey, darkest colour mostly close to the medium and in the centre of the colony, reverse dark olivaceous-grey, agar not pigmented. Hyphae smooth or verruculose, bright, olivaceous, septate, branched, 3,0-5,0 $\mu \mathrm{m}$ diam. Conidiophores mononematous, macronematous, unbranched, sterile portion slender, flexuous light olivaceous, verruculose, septate, 1,5-5,0 $\mu \mathrm{m}$ diam., conidiogenous part smooth, septate, geniculate, normally with two geniculations per cell, conidiogenous cells polytretic (2-3 pores per cell), 30,0$330,0 \times 4,0-5,0 \mu \mathrm{m}$. Conidia single, dry, acropleurogenous, olivaceous-brown, smooth, 3-4 pseudoseptate (usually 3), oblong ellipsoidal, straight, prominent scar on basal cell slightly protuberant (not a hilum), basal and apical ends of conidium slightly less pigmented at maturity, occasionally constricted at the septa, $19,0-26,0 \times 7,5-12,5 \mu \mathrm{m}$ ave. $22,7 \times$ 9,7 $\mu \mathrm{m}$.

Specimen examined: P.U. Culture Collection no. 1286, PREM 45013 dried culture on oatmeal agar.
As Drechslera species show considerable variation on different media, this isolate was cultured on potato-carrot agar and maizemeal agar as well. The colony characteristics did not vary appreciably, although growth on potato-carrot agar was slower and less profuse. Dimensions of the conidia, however, differed. On maizemeal agar the conidial dimensions were $14,0-25,0 \times 9,0-12,5$ ave. $22,9 \times 9,8 \mu \mathrm{m}$ and on potato-carrot agar they were $19,0-31,0 \times 7,5$ 10,0 ave. $25,6 \times 8,9 \mu \mathrm{m}$. The most constant feature of this fungus found on the different media is the predominance of conidia with three pseudosepta.

This is the first record of this species in South Africa.

Cladosporium macrocarpum Preuss in De Vries, Bibliotheca Mycologia 3, 76-81 (1952). Ellis in Dematiaceous Hyphomycetes, Kew: Commonwealth Mycological Institute (1971).

Figures 3, 14, 15, 16 and 17.

Colonies on $1,5 \%$ malt extract agar slow growing, attaining a diameter of $50 \mathrm{~mm}$ in 14 days at $25^{\circ} \mathrm{C}$. Mycelium velvety, undulated, olivaceous black, reverse of colony similar, no pigment diffusing into the agar. Hyphae smooth, septate, branched. slightly constricted at the septa, straight or flexuous, bright, olivaceous-green or olivaceous-brown, 5,0-8,75 $\mu \mathrm{m}$ diam. Conidiophores macronematous, mononematous, smooth, septate, flexuous, width fairly uniform over entire length, $124,0-310,0 \times 5,0-6,25 \mu \mathrm{m}$; conidiogenous part geniculate, tapering slightly towards the apex, conidiogenous cells polyblastic, integrated,
FIGs 14-18,-Cladosporium macrocarpum. 14, conidiophore and conidia; scanning electron micrographs of: 15 , conidia showing surface ornamentation $(\times 3200)$; 16 , attachment of conidium to conidiophore $[\times 3600 ; 17$, disc-like attachment scar of conidia $(\times 2240)]$. Verticillium fusisporium. 18, phialides on prostrate hypae. Bar in figures represents $10 \mu \mathrm{m}$.

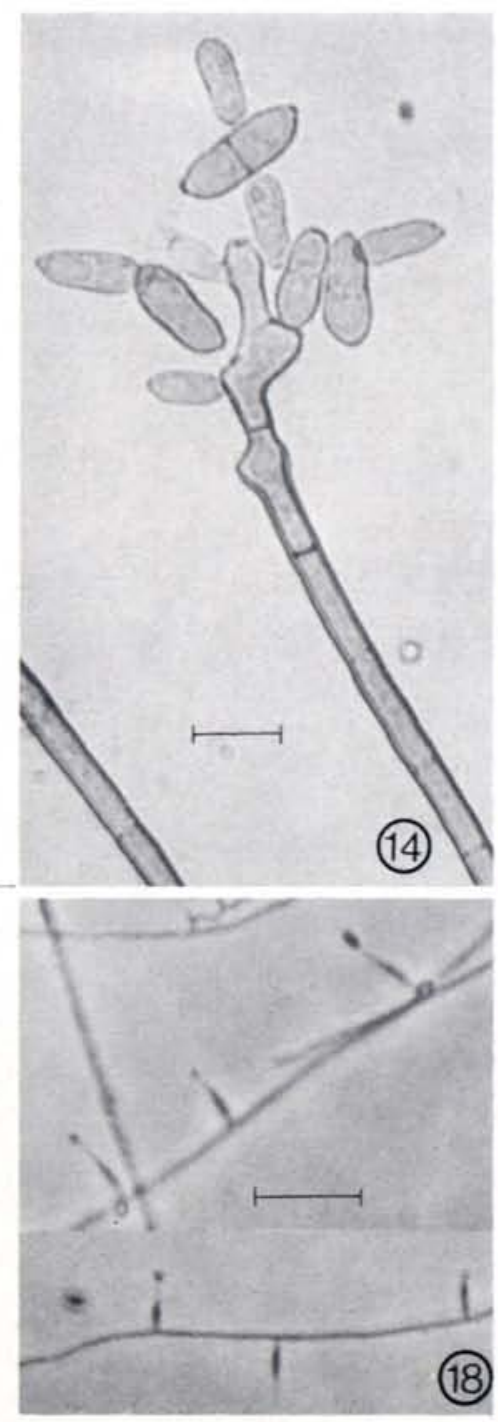

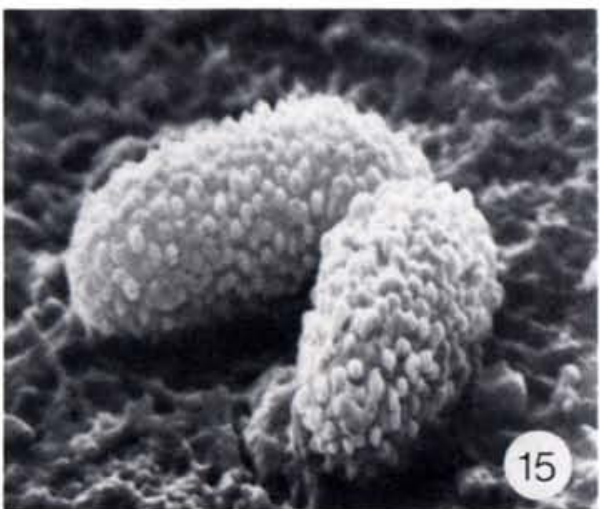

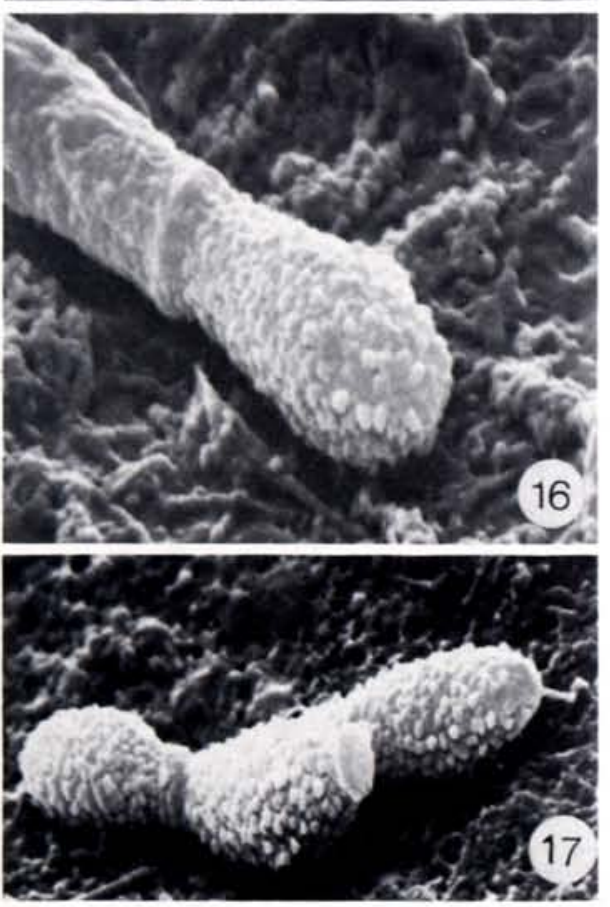


scars prominent, cicatrized and 1,0-1,5 $\mu \mathrm{m}$ diam. Conidia dry, catenate, acropleurogenous, bright, palebrown to olivaceous-brown, verrucose, subglobose, ellipsoidal or obovoid, 0-1 septate, often slightly constricted at the septum, basal and apical scars protuberant, ramoconidia absent, 12,5-22,5 ×5,0 $12,5 \mu \mathrm{m}$, ave. $17,3 \times 7,3 \mu \mathrm{m}$.

Specimen examined: P.U. Culture Collection no. 1234. PREM 45014 dried down culture on $1,5 \%$ malt extract agar.

The isolate described agrees in most respects with those of De Vries (l.c.) and Ellis (l.c.). The conidia with two or three septa, noted by these authors, were not found in this isolate. The nature of the verrucose surface of the conidia is shown in Figs 15-17 and can appropriately be described as densely tuberculate. The protuberant scars on the conidia appear to be disc-like structures.

Verticillium fusisporium W. Gams in Cephalosporiumartige Schimmelpilze, Stuttgart: Gustav Fischer Verlag (1971).

\section{Figures 4 and 18.}

Colonies on oatmeal agar grow rather slowly reaching a diameter of $45 \mathrm{~mm}$ in 10 days. Mycelium dense, cottony, raised, white, reverse of colony white, no pigment diffusing into the agar. Hyphae smooth, septate, branched, hyaline, 1-2 um diam., occasionally encrusted in small crystals. Phialides smooth, hyaline, thin-walled, lageniform with a narrow neck or somewhat subulate, arranged on prostrate hyphae in whorls of 2-4, whorls somewhat distant, phialides occasionally single and alternately spaced on fertile hypha, $6,25-11,25 \times 1,25-1,8$ ave. 7,9-1,5 $\mu \mathrm{m}$. Conidia smooth, hyaline, slimy, accumulating in small droplets at the tips of the phialides, fusiform, curved fusiform, obovoid or ovoid, $2,5-6,5 \times 1,5-2,5$ ave. 3,9-1,9 $\mu \mathrm{m}$, length: width ratio 2,03:1. Chlamydospores smooth, hyaline, moderately thick-walled, ovoid, borne on short hyphal branches $5,0-6,0 \times 3,0-4,0$ $\mu \mathrm{m}$.

Specimen examined: P.U. Culture Collection no. 1288 PREM. 45015 dried culture on oatmeal agar.
This isolate does not completely correspond with the type as described by Gams (l.c.). In culture it does not form the cherry-red colour in the agar, which is characteristic of the type; furthermore the phialides are smaller and only rarely subulate and the conidium morphology shows a greater variation. The presence of chlamydospores is a characteristic of this isolate, which has not been observed in the type.

The identity of this species has been determined by Dr W. Gams of the Centraal Bureau voor Schimmelcultures, Baarn.

This is the first record of the species in South Africa.

\section{ACKNOWLEDGEMENTS}

The financial support of the Department of Agricultural Technical Services and the C.S.I.R. is gratefully acknowledged. Prof. M. C. Papendorf is thanked for his guidance and the reading of the manuscript. Dr V. L. Hamilton-Attwell of the Department of Zoology of this University is thanked for the scanning electron microscopy and $\mathrm{Mr} \mathrm{E}$. Schults for preparation of some of the micrographs. The Director of the Centraal Bureau voor Schimmelcultures is thanked for making available cultures of U. botrytis.

\section{UITTREKSEL}

Vier fungus spesies wat uit stoppels van 'n koringland in die Heilbron distrik geïsoleer is, word beskryf nl. Ulocladium botrytis Preuss, Drechslera australiensis (Bugnicourt) Subram. \& Jain ex M. B. Ellis, Cladosporium macrocarpum Preuss, Verticillium fusisporium W. Gams.

\section{REFERENCES}

CoHen, A. L., 1970. Critical point drying. In M. A. Hayat, Principles and techniques of electron microscopy: biological applications. New York: Van Nostrand Reinhold Co.

Jooste, W. J., 1976. The mycoflora of wheat field debris, Part II. Bothalia 12: 129-131.

PAPENDORF, M. C. \& JoOste, W. J., 1974. The mycoflora of wheat field debris, Part I. Bothalia 11: 207-210. 